\title{
Tüketicilerin Kadın Temalı Reklamcılık Uygulamalarına İlişkin Değerlendirmeleri: Kalitatif Bir Araştırma
}

\section{Zehra Bozbay}

Doçent Dr. İstanbul Üniversitesi İşletme Fakültesi

Pazarlama Anabilim Dalı zehrat@istanbul.edu.tr

Orcid: 0000-0002-2728-8003

\section{Aylin Ecem Gürşen}

Araştırma Görevlisi

Galatasaray Üniversitesi Iktisadi ve İdari Bilimler Fakültesi İşletme Bölümü aegursen@gsu.edu.tr

Orcid: 0000-0003-3126-1644

\section{Habib Mehmet Akpınar}

Doktora Öğrencisi İstanbul Üniversitesi Sosyal Bilimler Enstitüsü Pazarlama Doktora Programı m.akpinar@windowslive.com Orcid: 0000-0002-7035-4168

\section{Özlem Yaman Komitoğlu}

Doktora Öğrencisi İstanbul Üniversitesi Sosyal Bilimler Enstitüsü Pazarlama Doktora Programı okomitoglu@gmail.com

Orcid: 0000-0002-2397-9229

Consumer Evaluations Towards Women-Themed Advertising Practices: A Qualitative Research

\section{Abstract}

Advertisements that put particular emphasis on the gender equality and show a growing body of "girl power" theme recently, are stated as "femvertising" which is the combination of French 
word of woman (femme) and English word of advertising in literature. Femvertising themed advertisings emphasize on women's power. It is possible to evaluate these ads as a result of globalization and the changing structure of women's role in society. In this study, it was aimed to determine whether consumer perceptions of these advertisements and these perceptions' changes according to gender. Within the scope of research, in- depth interviews were conducted with 15 people and the data obtained from the questionnaire were subjected to descriptive content analysis. As a result, it was found that female and male consumers' views on the advertisements were generally different. In addition, it has been found that femvertising themed ads can be represented by a limited group of products and that the image of women in advertisements may represent a very limited part of our country. However, it is among the findings of the study that it was suitable for the target market and didn't carry social mission but it could be accepted positively in terms of increasing awareness. It was found that consumers expect some concrete benefits from the companies that are used femvertising in their ads, findings showed that the commercial concern about the ads is perceived as a fashion.

Keywords: Advertising, femvertising, qualitative research, in-depth interview.

\section{Les évaluations des consommateurs concernant les applications publicitaires sur le thème de la femme: une recherche qualitative}

Résumé

Les publicités récentes utilisant le thème du "pouvoir des femmes" et qui misent l'accent sur l'égalité entre les sexes se sont désignées sous le mot-valise "femvertising". Ce mot est composé du mot français "femme" et duanglais "advertising". Ce type de publicité a le but d'attirer l'attention au pouvoir des femmes. Il est possible d'évaluer ces publicités comme un produit de la mondialisation et de l'évolution du rôle des femmes dans la société. Cette étude vise à déterminer les perceptions des consommateurs concernant ces publicités et voir si ces perceptions changent en fonction du sexe. Pour ce but, des entretiens approfondis ont été menés avec 15 personnes et les données obtenues à partir du questionnaire ont été soumises à une analyse de contenu descriptif. En conséquence, il a été trouvé que les avis des consommateurs variaient selon le sexe. En outre, il a été constaté que ce genre des publicités peut être appliquées à un groupe de produits limité et que l'image de la femme dans ces publicités ne peut représenter qu'une partie très restreinte de notre pays. On peut conclure que ce sont des publicités qui conviennent à leur marché cible, mais pour la même raison, elles ne peuvent pas être chargées d'une mission sociale. Cependant, on doit accepter aussi qu'elles créent une certaine conscience et augmentent la visibilité des sujets concernant le "pouvoir des femmes". Aussi, il a été constaté que les consommateurs attendent des preuves concrètes de la 
part des entreprises réalisant ce type de publicités puisque tous les participants soulignent que la mission principale des publicités est indéniablement commerciale. En outre, il est possible de dire que la plupart des participants voient ce courant comme un "mode".

Mots-clés: Publicité, femvertising, recherche qualitative, entretien approfondi.

\section{Öz}

Cinsiyet eşitliğine vurgu yapan ve son dönemde sayısı artan "kadın gücü" temalı reklamlar literatürde Fransızca kadın (femme) ve ingilizce reklam (advertising) kelimelerinin birleştirilmesiyle "femvertising" kavramı olarak ifade edilmektedir. Kadın temalı reklamlar, kadın gücüne vurgu yapan reklamlardır. Bu reklamları küreselleşme ve kadının toplum içindeki rolünün değişmesinin bir ürünü olarak değerlendirmek mümkündür. Bu çalışmada, söz konusu reklamlara yönelik tüketici algılarının ve bu algıların cinsiyete göre değişip değişmediğinin belirlenmesi amaçlanmıştır. Çalışmada 15 kişi ile derinlemesine görüşmeler gerçekleştirilmiş, soru formundan elde edilen veri betimsel içerik analizine tabi tutulmuştur. Sonuçta, kadın ve erkek tüketicilerin söz konusu reklamlara bakışının genellikle farkı olduğu bulgusuna ulaşıImıştır. Bunun yanı sıra, kadın temalı reklamların sınırı bir ürün grubuna uygulanabileceği ve reklamlardaki kadın imajının ülkemizin çok sınırlı bir bölümünü temsil edebileceği bulunmuştur. Ancak, hedef pazarına uygun olduğu, reklamlara sosyal bir misyon yüklenemeyeceği yine de farkındalığı arttırması yönüyle olumlu karşılanabileceği çalışmanın bulguları arasındadır. Tüketicilerin bu çalışmalara girişen işletmelerden somut birtakım faydalar beklediği ve söz konusu reklamlardaki ticari kaygının yadsınamazlığı reklamlardaki bu eğilimin gelip geçici bir moda olarak algılandığı bulgularına da ulaşılmıştır.

Anahtar Kelimeler: Reklam, kadın temalı reklamcılık, kalitatif araştırma, derinlemesine görüşme. 


\section{Giriş}

Kadın temalı reklamcılık kavramı, literatürde ve internet ortamında kadının gücüne vurgu yapan reklamlar için kullanılan bir terimdir. Akestam ve diğerleri (2017), kadın temalı reklamcılığı (femvertising) geleneksel kadın stereotiplerinin dışına çıkan reklamlar olarak tanımlamıştır. İnceoğlu ve Onaylı-Şengül (2018) ise, çalışmalarında bu yaklaşımı "kadın odaklı reklamcılık" olarak tanımlamışlardır. Küreselleşme ve sınırları ortadan kalkan yeni dünya düzeni ile tüketici anlayış ve davranışlarında değişimler meydana gelmeye başlamıştır. Farklı coğrafya ve yaşam tarzına sahip insanların birbirleriyle kolayca iletişime geçmesi, insanların ufuklarının açılmasında da önemli rol oynamıştır. Dinamikleri toplumsal değişimlere kökten bağlı olan pazarlama etkinlikleri de çeşitli şekillerde kendisini bu yeni düzene uyumlandırmaya çalışmaktadır. Kadın temalı reklamcılık kavramı, kadının toplumdaki yerinin değişimini yansıtan bir reklam ve pazarlama çabası olarak nitelendirilebilir. Ancak, bilindiği gibi pazarlama etkinlikleri çoğu zaman samimiyeti sorgulanan etkinliklerdir. Reklam ve iletişim çalışmalarını ticari kaygının bir ürünü olarak gören tüketiciler her zaman "hassas konulara" dokunan reklamlara şüpheyle bakmaktadır.

Kadın temalı reklamcılık kavramına ilişkin literatür araştııılığında, bu yaklaşıma ilişkin birbirinin zıttı görüşlerle karşılaşılmaktadır. Bazıları yaklaşımı yüzeysellikle ve feminizmin içinin boşaltılması, ticarete konu edilerek değersizleştirmeye çalışıması olarak görürken; bazıları ise bu uygulamalara daha sıcak bakmakta, uygulamanın toplumdaki değişimi yansıttığını, farkındalık yaratmakta bir araç olduğunu belirtmektedirler (Johnston ve Taylori 2008; Murray, 2013; Beale ve diğerleri, 2016).

Ulaşılabilen internet ortamındaki pazarlama/reklam eksenli sitelerde ve akademik veri tabanlarında kadın temalı reklamlardan bahsedilmeye 2014 yılında başlandığı saptanmıştır (Mahdawi, 2014; Zmuda ve Diaz 2014; Zotos ve Tschila 2014; https://www.theguardian.com/commentisfree/2014/apr/23/feminism-adverts-great-way-sell-stuff). Söz konusu reklamların çekilmeye ve yayınlanmaya devam edilmesiyle birlikte ilerleyen yıllarda konuya ilişkin haberler ve akademik çalışmalar yapılmıştır. Buna karşın, literatür incelendiğinde konunun genellikle teorik olarak ele alındığı, tüketici yönlü bakış açısına sahip çalışmaların oldukça kısıtlı olduğu görülmüştür. Bu çalışma bu boşluktan yola çıkılarak oluşturulmuştur. Çalışmada, kadın temalı reklamların tüketiciler tarafından nasıl algılandığı, bu algılamaların kadın ve erkek tüketiciler arasında farklıık gösterip göstermediği derinlemesine görüşmeler ile tespit edilmeye çalışılmıştır.

\section{Postmodernizm ve Tüketici}

Firat ve Venkatesh (1995), modernizmin genel geçer açıklamaları benimseyen bakış açısını sığ bir gelenekçilik olarak nitelemiş ve postmodern bakış açısının tüketimi anlamada önemli açılımlar sunabileceğine dikkat çekmişlerdir. Postmodernizm, tüketim toplumunun doğası ile örtüşen bir akımı temsil etmektedir. Tü- 
ketim toplumu, reklamlar ve postmodernizmin iç içe geçmiş ve günümüz sistemini temsil eden kavramları olarak düşünülmektedir (Baudrillard, 1998).

Postmodernizmle birlikte, tüketici davranışını anlamanın ve açıklamanın tek bir yöntemi olmadığı düşüncesi ön plana çıkmıştır (Goulding, 2003). Fırat (1991), postmodern dünya düzenindeki yeni tüketiciyi anlamak için bu kavramın derinlemesine ele alınması gerektiğini vurgulamıştır. Miles (1999), postmodern bakış açısının tüketiciyi anlamada kullanılabilmesi için daha esnek ve yaratıcı yaklaşımlar benimsenmesi gerektiğini vurgulamıştır. Tüm bu gerekçeler, postmodern tüketiciyi anlamanın nitel gerekliliğini ortaya koymaktadır (Goulding, 2003). Buna ek olarak, Simmons (2008) narsisizm, kendini soyutlama ve yalnızlık ile tanımlanabileceğini söylediği postmodern tüketicilere ulaşmada internetin önemli bir araç olduğuna vurgu yapmıştır. Buna gerekçe olarak, internetin doğrudan, gerçek zamanlı, kişiselleştirilmiş etkileşimlere olanak tanıması gösterilmiştir. Dolayısıyla, postmodernizmin, feminizm ve internet teknolojileriyle yakından ilişkili bir kavram olduğunu ve günümüz popüler kültürünün kaçınılmaz bir parçası olduğunu söylemek mümkündür.

\section{Feminizm ve Pazarlama}

Pazarlama etkinlikleri açısından, dalga olarak nitelenen dört farklı feminizm yaklaşımından bahsedilmektedir. 1850'lerde Sufragette hareketi ile ortaya çıkan feminizm akımı, ilk dalga olarak kabul edilmektedir. Bu dönemde, pazarlama etkinlikleri, davalarını geniş kitlelere duyurmada feministlerin de kullandığı bir araç olarak karşımıza çıkmaktadır (Scott, 2005'ten aktaran Maclaran, 2015). 1960-1980 yılları arası, ikinci dalga dönemi olarak kabul edilmekte, bu dönemde pazarlama karşıtı metinler ön plana çıkmaktadır. Bu metinler, reklamlarda kadın bedeninin metalaştırılmasını ve kadınlara domestik roller biçilmesini eleştirmektedir. 1990'ı yıllarda ortaya çıkan üçüncü dalga, ırk, cinsiyet, sosyal sınıf, yeterlilik, etnik kimlik gibi kavramlarla birlikte feminizmi ele almaktadır. Dördüncü dalga ise, popüler kültürle birlikte cinselliğin normalleştirildiği dönemi ifade etmektedir. Pazarlama etkinliklerinin bu normalleştirme sürecine moda, müzik endüstrisi ve sosyal medya ile hizmet ettiği kabul edilmektedir (Maclaran, 2015). Sosyal medya feminizmi olarak da adlandırılan dördüncü dalga feminizm, günlük hayatta cinsiyetçiliğin sebep olduğu durumların tartışılabileceği bir ortam sunmaktadır. Dördüncü dalga, fikir paylaşımı, küresel politikaya katııım ve kesişimler üzerine kuruludur (Retallack ve diğerleri, 2016).

Feminizm, her zaman medya ile ilişkilendirilen bir kavram olmuştur. Feminizmin medya ile ilişkisinin sonuçları kızgınlık, kışkırtıcııı ve katılımcılık gibi farklı şekillerde dişa vurulmuştur (Lilburn ve diğerleri, 2000). Özellikle reklam etkinliklerinde feminizm ve kadın etkisini hissetmek mümkündür. Bu durumun erken örneklerinden biri olarak 1960'larda Virginia Slims'in ürünlerini pazarlamak için güçlü kadın imajına vurgu yaptığı reklamlar gösterilmiştir. Buna karşın, toplumda kadının rolünün dönüşümü ve feminist yaklaşımın anlaşılırlığının ve etkisinin artmasıyla 
birlikte kadının reklamdaki rolünün de değiştiğini gözlemlemek mümkündür. 20. yüzyıl boyunca reklamlarda ev işlerinin nasıl daha kolay yapılacağını, nasıl daha temiz eş ve anne olunacağını, nasıl pasif ve yerel birer ev kadını olunacağını dikte eden erkek sesleri 1970'lerle birlikte farklılaşmaya başlamıştır (Baxter, 2015).

1970'li yılların başından bu yana, reklamlarda kadınlara ve erkeklere biçilen roller akademik çalışmalarla da araştııımaktadır. Reklamcılar, mal ve hizmetlerini pazarlamak için toplumda genel kabul görmüş cinsiyet rolleri üzerinden reklam etkinliklerini gerçekleştirmektedir. International Journal of Advertising, 2016 yılında "Reklamda Cinsiyet Stereotipleri" başlıklı bir sayı yayınlamıştır (Grau ve Zotos, 2016). 1970-2002 yılları arasında dünya genelinde cinsiyetle ilişkili reklamları inceleyen bir çalışma, reklamlarda stereotipleştirmenin git gide azaldığını, buna karşın reklamların kadınları ve erkekleri farklı etkilediğini ortaya koymuştur (Wolin, 2003). Feminist hareket ve toplumdan kadının değişen rolünün etkisiyle reklamlardaki farklı kadın tasvirlerini ele alan bir çalışma, bu tasvirleri dört başlık altında toplamıştır. Bunlar, "geleneksel rollerdeki kadınlar", "dekoratif rollerdeki kadınlar", "geleneksel olmayan rollerdeki kadınlar" ve "erkekle eşit tasvir edilen kadınlar"dır (Zotos ve Tsichla, 2014).

Pazarlama etkinliklerine feminist bakış açısı, 1990'lı yılların başında ortaya çıkmıştır. Cinsiyet, pazarlama etkinlikleri açısında önemli bir pazar bölümlendirme aracıdır. Bunun yanında, yine aynı dönemde pazarlama, reklam ve pazarlama araştırması gibi alanlarda kadınların görünürlüğü artmaya başlamıştır. Bununla beraber, pazarlamaya feminist bakış açısının Frankfurt Okulu ya da postmodernizm gibi pazarlamaya yalnızca yeni bir bakış açısı getireceği düşüncesi bu akımın yanIış değerlendirilmesine neden olmuştur (Catteral, Maclaran ve Stevens, 1997).

Feminizmin reklam etkinliklerinde kullanılması feminizm savunucuları tarafından hoş karşılanmamaktadır. Feministler, bu tarz etkinlikleri değişim yaratma kapasitesinden yoksun ve sadece farkındalık yaratabilecek yüzeysel çabalar olarak görmektedir. Femininistlerin bir diğer argümanı, reklamların hedef kitlesi çoğunlukla kadınlarken, reklamları ortaya çıkaranların erkekler olmasıdır. Baxter (2015) bu akımın "ad-her-tising" olarak da adlandırıldığını belirtmiştir. Çalışmasında bu reklamları kadını güçlendiren, feminizm, kadın aktivizmi, kadın liderliği ve eşitliği gibi konulara odaklanan reklamlar olarak tanımlamıştır. Ancak bu reklamlar da samimiyetsiz olarak değerlendirilmiştir (Baxter, 2015). Söz konusu reklamlar sabun köpügü gibi gelip geçici olarak nitelenmekte, bu reklamlarla "pembe yıkama" (pink washing) yapıldığı belirtilmektedir (Zmuda ve Diaz, 2014). Basının ve pazarlamanın feminizmi ürünleri satma amaçlı kullanmaları sıklıkla eleştirilmektedir (Mahdawi, 2014). Plank (2014) ise, beğenilsin ya da beğenilmesin kadın temalı reklamların kendisinden bahsettirdiğini kabul etmek gerektiğini belirtmiştir.

Maclaran'ın (2015) pazarlama etkinliklerinde kadını ne şekilde kullanıldığına ilişkin literatür analizinde, feminizmin pazarlama etkinlikleri itibariyle tanımının ve işlevinin değiştiğini ortaya koymuştur. Dans (2018) gerçekleştirdiği nitel çalışma 
ile bu tür reklamların pazarlama iletişiminde tüketicilerle kişisel değerleri üzerinden iletişime geçmede ve onları ikna etmede etkili olduğunu ortaya koymuştur.

Lazar (2006) da reklamlarda güçlü kadın imgesini Singapur örnekleminde incelediği çalışmasında yeni ve popüler "post-feminizm" akımının medya-dostu ve tüketici odaklı bir yapıda olduğunu belirtmiştir. Gill (2008) pasif, güçsüz ve edilgen kadın imajının dönüşümüne dikkat çekerek günümüzde reklamlarda aktif, güzel, güçlü ve akıllı kadınları tasvir edilmeye başladığını belirtmiştir. Marcus Reker (2016), "genç kızlar" üzerinden yürütülen feminist reklam etkinliklerinin feminist ideolojiyi ve aktivizmi pazarlayarak satın alma gücüne dönüştürmeye çalıştığını ancak bu yaklaşımların aslında sistematik cinsiyet eşitsizliğinin olduğu toplumda satın almanın ötesine geçemediğini ifade etmiştir.

Alkan (2016), güçlü kadın imgesinden yola çıkarak oluşturulan reklamları incelediği eleştirel çalışmasında kadınları güçlendirme söylemindeki reklamların aynı zamanda ticari hedeflere ulaşma kaygısında olduklarının altını çizmiştir. Aile ve iş yaşamında kadının rolündeki değişiminin reklamlara da yansıdığına değinen bir diğer çalışma reklamcılıkta üzerinde durulması gereken üç unsura dikkat çekmiştir. Bu unsurlar, dijital platformlardaki reklamlarda kadın ve erkek temsilleri, daha önce görmezden gelinen LGTB (lezbiyen, gey, transseksüel ve biseksüel) bireylere yönelik reklamlar ve güçlü kadın imajına vurgu yapan kadın temalı reklamlar olarak belirlenmiştir (Grau ve Zotos, 2016).

Johnston ve Taylor (2008), kadın temalı reklam yürüten bir kişisel bakım markasının bu yaklaşımını güzellik algısını kırmasına rağmen kadınların güzel hissetmelerinde ve kendilerine güvenmelerinde kendi ürününü bir araç olarak sunması yönüyle eleştirmiştir. Bir başka çalışma, aynı markanın söz konusu reklam kampanyasının farkındalık yaratması noktasında olumlu karşılanabileceğini söylemiştir (Murray, 2013). Batı'nın güzellik ideallerine karşı çıkan reklamlara genç tüketicilerin tepkisini, aynı markanın reklamları üzerinden ele alan bir çalışma, genç tüketicilerin bu reklamlara olumlu tutum geliştirdiğini ortaya koymuştur. Buna karşın çalışmada, söz konusu reklamların şişman/zayıf gibi cinsiyetçi tanımları yine de vurguladığını ve dolayısıyla yine de sorunlu olduğunu belirtmiştir (Beale, Malson ve Tischner, 2016).

Toplumda kadının değişen rolünü açıklamada cinsiyet kimliği kavramı da önemlidir. Cinsiyet kimliği, geçmişte doğuştan gelen, dişil ve eril olmak üzere ikiye ayrılan kısıtlı ve kısıtlayıcı bir kavramı simgelerken günümüzde anlam değiştirmiştir. Postmodern tüketici kültüründe cinsiyet kimliği tüketicilere ürünler, eşyalar ve çeşitli yapılarla dahil olabilecekleri adeta maskeli balodaki maskelere benzetilmiştir (Kacen, 2000). Fischer ve Arnold (1994), cinsiyet, cinsiyet kimliği ve cinsiyet rollerine karşı tutumun birbirinden farklı kavramlar olduğunu kantitatif bir çalışma ile ortaya koymuştur. Bu çalışmada aynı zamanda tüketici davranışını anlamada bu kavramların tek tek ve toplu etkilerinin de göz önünde bulundurulması gerektiği belirtilmiştir. 


\section{Reklam ve Kadın Temalı Reklamcılık}

Pazarlama kampanyalarında kadın gücü temasını ön plana çıkarmak son dönemlerde reklamlarda sıklıkla görülmektedir. Kadın tüketiciler üzerinde gerçekleştirilen bir araştırma söz konusu reklamların markaya ilişkin görüşler, satın alma niyeti ve marka ile kurulan duygusal bağ üzerinde pozitif etkiye sahip olduğunu ortaya koymuştur (Drake, 2017).

İşletmelerin başarılı olması açısından tüketicilerini anlaması, onların intiyaç ve isteklerini belirleyerek onlara eşsiz bir değer önerisi yaratması önemlidir. Hedef kitlesini kadın tüketicilerin oluşturduğu işletmeler kadınların davranışlarını yakından takip etmeli ve onlara uygun mesajları iletişim faaliyetlerinde kullanmalıdır. Tüketicilerin alışkanlıkları, ihtiyaçları ve istekleri doğrultusunda satın aldıkları mal ve hizmetler çok fazla değişiklik göstermese de reklam mesajlarında değişiklikten söz etmek mümkündür (Baxter, 2015).

Kadın temalı reklamclık geleneksel kadın imajına meydan okuyan bir reklamcılık olarak tanımlanmaktadır (Akestam ve diğerleri, 2017). Literatürde yer alan diğer bir tanıma göre ise kadın temalı reklamcılık; kadınları, feminizmi, kadın aktivizmini, kadın liderliğini, eşitliğini konu alan ve kadınları hedefleyen reklamcılık faaliyetleri olarak açıklanmaktadır (Baxter, 2015). Kadın temalı reklamcılık başka bir ifadeyle kadının toplumdaki rolü için farkındalık yaratmaya ve klişeleri yeniden şekillendirmeyi amaçlayan pazarlama kampanyalarıdır (Kapoor ve Munjal, 2019). Kadın temalı reklamcılık feminizm ile ilişkilidir ancak bu reklamlar feminizmi savunmamaktadır. Reklam faaliyetlerinin en önemli amacı markanın stratejik amaçlarına hizmet etmesidir. Yine de kadın temalı reklamların kadınların güçlenmesine ve özgürlügüne gerçekten katkıda bulunması beklenmektedir (Qiao ve Wang, 2019).

Literatürde kadın temalı reklam kampanyalarını inceleyen Becker-Herby (2016), bu reklamların taşıdığı beş özellik olduğunu ileri sürmüştür. Bu özelliklerden ilki reklamlarda kadınlara özgü özelliklerin kullanılması, ikincisi kadın temalı reklamların doğası gereği kadınları motive edici ve kendine güven verici duyguları sağlayıCı mesajlar vermesi, üçüncüsü geleneksel olarak ev işleri ile uğraşan, kadınlık görevlerinin dışına çıkan, klişelere karşı çıkan yapısının olması, dördüncüsü ise reklamlarda erkek bakış açısına hitap etmeyen cinselliğin yer almasıdır. Bu tür reklamlarda makyaj ve gerçekçi olmayan cinsellik çok nadir olarak görülür. Son özellik olarak ise reklamlarda kadınlara ait özelliklerin özgün olarak tasvir edilmesidir. Günümüzde markalar tüketicilerle ilişkilerini geliştirirken sosyal konulara odaklanmaktadırlar. Bu noktada işletmelerin kadın temalı reklam mesajını tüketicilere nasıl iletecekleri ve bu mesajın markaya olan uyumu önemlidir. Yapılan bir çalışma kadın temalı reklam etkinliklerinin hem düşük hem de yüksek uyum durumunda tercih edilebilecek bir seçenek olduğunu ortaya koymuştur (Champlin ve diğerleri, 2019).

Kadın temalı reklamları kullanan markaların bu reklamları tercih etmesinin çeşitli nedenleri vardır. Bu nedenlerden biri marka kimliklerini politik ve kültürel 
olarak bilinçli ve cinsiyet eşitliğine önem veren bir kimlik olarak konumlandırmalarıdır. Diğeri ise kamuoyuna karşı açık bir şekilde kadın haklarını savunucusu rolü üstlenerek kurumsal sosyal sorumluluk etkinliklerine katkıda bulunmalarıdır. Kadınların satın alma karar sürecindeki rolünün de kadınlara yönelik reklamları cazip hale getirdiği söylenebilir (Hunt, 2017).

\section{Araştırmanın Metodolojisi}

\section{Araştırmanın Amacı ve Kapsamı}

Araştırmanın amacı kadın temalı reklamcılık uygulamalarına yönelik tüketici algılarını tespit etmektir. Literatür incelendiğinde söz konusu akımı inceleyen çalışmaların genelde teorik düzeyde kaldığı ve konuyla ilgili reklam ve dokümanlar içerik analizine tabi tutularak gerçekleştirildiği görülmektedir. Bu çalışmanın önemi, söz konusu kadın temalı reklamcılık uygulamalarının tüketiciler gözünden derinlemesine incelenerek ortaya çıkarılmasıdır.

Araştırmanın amacı kapsamında uzmanlık alanları farklılaşan 15 kişiyle derinlemesine görüşmeler gerçekleştirilmiştir. Kadın ve erkek tüketicilerin algılarının farkllaşıp farklılaşmadığını belirlemek üzere farklı alanlarda uzmanlaşmış dokuz erkek ve altı kadın bireyle görüşülmüştür. Bu kişilere ilişkin özet bilgiler aşağıdaki tabloda yer almaktadır:

Tablo 1: Katılımcıların Sosyo-demografik Özellikleri

\begin{tabular}{|c|c|c|c|}
\hline Cinsiyet & Yaş & $\begin{array}{c}\text { Meslek/ uzmanlık } \\
\text { alanı }\end{array}$ & Kodu \\
\hline Kadın & 24 & Sosyolog & K1 \\
\hline Erkek & 38 & Özel Sektör Çalışanı & K2 \\
\hline Kadın & 37 & Özel Sektör Çalışanı & K3 \\
\hline Kadın & 29 & Özel Sektör Çalışanı & K4 \\
\hline Erkek & 30 & Özel Sektör Çalışanı & K5 \\
\hline Erkek & 30 & Özel Sektör Çalışanı & K6 \\
\hline Erkek & 32 & Özel Sektör Çalışanı & K7 \\
\hline Erkek & 41 & Akademisyen & K8 \\
\hline Erkek & 31 & Akademisyen & K9 \\
\hline Kadın & 26 & Uzman Psikolog & K10 \\
\hline Erkek & 31 & Özel Sektör Çalışanı & K11 \\
\hline Kadın & 30 & Akademisyen & K12 \\
\hline Erkek & 43 & Özel Sektör Çalışanı & K13 \\
\hline Kadın & 40 & Kamu Personeli & K14 \\
\hline Erkek & 29 & Akademisyen & K15 \\
\hline
\end{tabular}




\section{Örnekleme ve Veri Toplama Yöntemi}

Araştırmada, nitel araştırmada amaçlı örnekleme yöntemlerinden kolay ulaşılabilir durum örneklemesi yöntemi kullanılmıştır. Bu örnekleme türü, konunun tanıdık bir örneklem üzerinden çalışılmaya daha uygun olduğu düşünüldüğü için tercih edilmiştir (Yıldırım ve Şimşek, 2011).

Veri toplama yöntemi olarak standartlaştırılmış açık uçlu görüşme yöntemi kullanılmıştır. Standartlaştırılmış açık uçlu görüşme yöntemi, tüm cevaplayıcılara aynı soruların aynı sırayla sorulduğu, birden çok görüşmecinin olduğu nitel araştırmalar için önerilmektedir (Yıldırım ve Şimşek, 2011). Bu çalışmada birden fazla görüşmeciyle veri toplandığı için bu seçeneğin uygun olduğu düşünülmüştür.

Verilerin analizinde, betimsel analiz yönteminden yararlanılmıştır. Betimsel analizde görüşme öncesi belirlenen temalar doğrultusunda elde edilen veriler tasnif edilmeye çalışılmaktadır. Doğrudan alıntılara yer verilmekte, bulgular önceden belirlenmiş temalar ekseninde yorumlanmaktadır (Yııdırım ve Şimşek, 2011). Bu çalışmada da, elde edilen bulgular soru formu oluşturulurken belirlenen temalar ışığında değerlendirilmiş, yorumlama sürecinde pazarlamaya özel yapılabilecek yorumlara odaklanılmış ve en başta belirlenen temalar analiz sırasında genişletilmeye/detaylandırımaya çalışımıştır. Araştırmanın verileri Ocak- Şubat 2018 tarihleri arasında derinlemesine görüşme yoluyla toplanmıştır.

\section{Araştırmada Kullanılan Yarı Yapılandırılmış Soru Formu}

Derinlemesine görüşmelerde kullanılan yarı-yapılandııımış soru formu, konuya ilişkin literatür ve internet kaynaklarının taranması ile oluşturulmuştur. Internetteki ve literatürdeki kaynaklar incelendiğinde konunun dört tema altında ele alınabileceği düşünülmüştür. Bu alt başlıklar, "postmodernizm ve kadın temalı reklamcılık kavramlarının gelişimi", "feminizm ve toplumsal cinsiyet rollerinin algılanması", "kadın temalı reklamcılık kavramının kadınlar ve erkekler tarafından algılanması", "sosyal medyada paylaşım ve etkileşim" ve "marka-ürün-tüketici tercihi" olarak gruplanmıştır. Araştırma soruları bu alt başlıklar kapsamında oluşturulmuştur. Bu bağlamda, görüşmelerde kullanılan sorular ve soruların oluşturulmasında yararlanılan kaynaklar aşağıda yer almaktadır.

1. Feminizm ve kadın temalı reklamcılık arasındaki ilişki hakkında ne düşünüyorsunuz?

2. Tüketim toplumu içinde kadınların rolü hakkında ne düşünüyorsunuz? (https://spark.adobe.com/blog/2017/03/10/femvertising-what-is-it-andhow-to-do-it-well/)

3. Kadın temalı reklamcılık bir etiket mi, bir reklam taktiği mi, bir sosyal hareket mi?

4. Kadın temalı reklamcılık deyince ne aklınıza geliyor?

5. Hangi markalar aklınıza geliyor? 
6. Bir birey olarak kadın temalı reklamcılık yapan işletmelerin ürünlerini tercih eder misiniz?

7. Sosyal medyada bu tarz reklamları paylaşıyor musunuz? (https://spark. adobe.com/blog/2017/03/10/femvertising-what-is-it-and-how-to-do-itwell/)

8. Markaların feminizmi kullanması hakkında ne düşünüyorsunuz? Sizce bu iyi mi kötü mü, nasıl değerlendiriyorsunuz? (https://www.theguardian.com/lifeandstyle/2015/oct/12/femvertising-branded-feminism)

9. Kadınlara ilişkin "duygusal" ya da "olması gereken" olarak tanımlanabilecek bir durumun, tüketim toplumunun ya da reklamların bir parçası haline getirilmesi hakkında ne düşünüyorsunuz? (https://campaignjr. com/femvertising-gercekten-kadinlari-guclendiriyor-mu/)

10. İternette konu araştıııdığında kadın temalı reklamcılığı "reklamcılığın geleceği" olarak görmeye kadar giden düşüncelere rastlanmaktadır. Reklamlarda bu akım sizce gelecek vaat ediyor mu? Bir moda mı? Olması gereken bir şey mi? Bu sayede reklama sosyal bir misyon yüklendiği söylenebilir mi? (http://www.brandba.se/blog/femvertising)

11. Markaların kadın temalı reklamclık kapsamındaki reklamlarının işletmelerin kadın çalışan sayısı ve katkısı ile ilişkisi sizce önemli mi? Nasıl olmalı? Bu işletmelerdeki kadınların gelişim ya da sosyal haklarına ilişkin konularda ne durumda olduğunu biliyor musunuz? Bu konuyla ilgileniyor musunuz? (Becker-Herby, 2016)

12. Geleneksel ve çağdaş reklamlardaki kadın stereotipi hakkında ne düşünüyorsunuz? Değişim var mı? Hangi yönde? Bu değişimin kaynağı sizce işletme içinden mi pazardan mı geliyor? (Akestam ve diğerleri, 2017)

13. Kadın temalı reklamcılık uygulaması yapan işletme/ürün ile feminist bakış açısının uygun olması sizce önemli mi?

14. Bu reklamlar söz konusu işletme hakkındaki düşüncelerinizi etkiler mi? O ürünleri tercih etmenize neden olur mu?

15. Bu reklamlar feminizm hakkındaki düşüncelerinizi etkiler mi?

16. Cinsiyet eşitliğini savunmak ile feminizm sizce aynı şey mi? Bu iki kavramı kendi bakış açınıza göre tanımlar mısınız? Kendinizi feminist olarak tanımlar mısınız? Neden? (Abtibol ve Sternadori, 2016)

17. Feminizmi popülerleştirmek sizce doğru mu? Bu konuda ne düşünüyorsunuz?

18. Kadın temalı reklamcılık yapan işletme ya da markalarla duygusal bir bağ kurmanızın kolaylaştığını söyleyebilir misiniz? (Drake, 2017)

19. Feminizmin metalaştııılması hakkında ne düşünüyorsunuz?

20. Kadın temalı reklamcılık feminizm ile örtüşüyor mu yoksa onun tam tersi mi?

21. Pazarlama ve reklamcılıkta bu akım sizce çağdaş feminizm hakkında ne söylüyor? (Jalakas, 2016) 


\section{Araştırmanın Bulguları}

Araştırmanın bulguları, çeşitli başlıklar altında incelenmiştir. Bu başlıklar oluşturulurken, belirlenen temalardan yola çıkılmış, bu temalar cevaplayıcılardan elde edilen veri doğrultusunda pazarlama etkinlikleri ekseninde yorumlanmıştır. Buna göre araştırma bulguları aşağıdaki yedi başlık altında ele alınmıştır.

1. Katılımcıların feminizmin reklamlarla popülerleştirilmesine ilişkin görüşleri

2. Katıımcıların kadın temalı reklamların hedef pazarına ilişkin görüşleri

3. Katılımcıların kadın temalı reklamlardaki ürünlere ilişkin görüşleri

4. Kadın ve erkek katıımcıların kadın temalı reklamlara ilişkin görüşleri

5. Katılımcıların kadın temalı reklamların sosyal medyada paylaşılmasına ilișkin görüșleri

6. Katııımcıların kadın temalı reklamların ürünün değerlendirmelerine olan etkilerine ilişkin görüşleri

7. Katılımcıların kadın temalı reklamcılık yapan işletmelerden sosyal konulara ilişkin duyarlıık beklentilerine yönelik görüşleri

Aşağıda bulgulara ilişkin detaylı açıklamalar bu başı|ılar itibariyle yer almaktadır.

\section{Katılımcıların Feminizmin Reklamlarla Popülerleştirilmesine Illişkin Görüşleri}

Katılımcıların feminizmin reklamlar aracılığıyla popülerleştirilmesine yönelik görüşleri farklılık göstermektedir. Bu konuya kadın katılımcıların olumlu baktığı ancak erkek katılımcılar arasında görüş ayrılıklarının olduğu görülmüştür.

Olumlu bakış açılarına örnek olarak kadın katılımcılardan birinin aşağıdaki ifadesi gösterilebilir.

"Reklamların toplumun dinamiğini etkileyen ve bu dinamikten beslenen bir işleyişi var. Bu etki-tepki işleyişinde feminizmin gündeme geliyor olmasını da olumlu buluyorum. Reklamların her kesimin, her an ulaşabileceği ve yapısı sebebiyle bir şekilde akılda kalıcılığı var. Bunlar da göz önüne alındığında reklamların bir meseleyi daha kısa sürede gündeme getirip çok uzun süre hafızalarda tutmaya yarayan yapısı feminizm gibi söylenmekten geri durulan ve maalesef kötü bir algısı olan terimleri gerek olumlu hale getirmeye gerek gündem yapmaya yarayabilir." (K1)

Erkek katılımcılardan konuya olumlu yaklaşan bir katılımcının ifadesi ise aşağıdaki gibidir.

“...popülerleşmeye başlayınca biraz asıl ideolojik amacından uzaklaşabiliyor o bakımdan çok doğru olmayabilir ama bir yandan 
da popülerleşmesi bu hakları bir yerde söylediğinden en azından herkesin kulağına bir kere çalınmış ya da bir yerde görmüş olduğu için daha güçlü dile getirebilmek açısından önemli oluyor." (K3)

Olumsuz yaklaşıma örnek olarak ise aşağıdaki erkek katılımcıların ifadeleri gösterilebilir.

"Türkiye şartlarında her gün kadın cinayetleri olurken, her gün kocalarından şiddet gören kadınlar varken feminizmi popülerleştirmek bu cinayetlerin ve bu şiddetlerin artmasına sebebiyet verir. Feminizm maalesef Türk toplumunda erkeğin vurduğu tokatla yok olan bir kavram." (K2)

"Bence reklam malzemesi yapılmaması gerekiyor, buradan yani kadınlar üzerine zaten hep oynanıyor, reklamlar da onların üzerine dönüyor, onların üzerinden daha çok para kazanılıyor, ama toplumda kadınlar eşit değiller, kadın erkek eşitliği yok, hep ikinci planda her ne kadar okusalar, çok iyi yerlere gelseler de yine kadınlar ikinci planda bizim toplumumuzda." (K8)

\section{Katılımcıların Kadın Temalı Reklamların Hedef Pazarına İlişkin Görüşleri}

Katılımcılar söz konusu reklamlardaki kadın imajının toplumumuzun küçük bir kesimini yansıttığı konusunda hemfikirdir. Buna karşın, katıımcıların bir kısmı bu sebeple reklamları etkisiz-gereksiz bulurken, bir kısmı ise reklamların belirli bir kesimi yansıttığını ancak diğerlerine de ilham olabileceğini düşündüğünü söylemişlerdir. tadır.

Olumsuz görüşlere örnek olarak katılımcıların ifadeleri aşağıda yer almak-

"Sadece okumuş, alım gücü yüksek, iyi eğitim almış kadınların ki bana kalırsa bu Türkiye ortalaması dikkate alınırsa sadece \%30'luk kesimin ağzına bal çalarak bakın böyle kadınlarımız var biz her şeyi başarırız algısını vererek o markanın ürünlerini almaya çalışan basit reklamlardan oluşuyor. Köyde tarlada çalışan teyze de akşam bu reklamlara denk geliyor vay be böyle insanlar varmış diye izleyip görücü usulü evlendirildiği kocasının ayaklarını yıkamaya devam ediyor." (K2)

"Hayır, kesinlikle. Pembe dizilerle beyinleri yıkanmış ülkemin pembe hayalleri bunlar." (K8)

Bir başka katılımcı ise reklamların toplumun küçük bir kesimini yansıttığını kabul etmekle birlikte hedef pazarına uygun olduğunu belirtmiştir.

“...bir sürü pazar analizleri, anketler, çalışmalar vs. olduğu için daha çok pazarın ihtiyacına göre hangi gruba ne satmak istediklerine göre 
biçimleniyor... sanki İstanbul, İzmir gibi büyük şehirlerde yaşayan kadınlara seslenircesine, çünkü artık bu kadınlar çok bakımlı ve kendilerini daha güçlü hissetmek istiyorlar, çünkü yalnız yaşıyorlar, evlenmenin o kadar öncelikli gerekli olmadığını düşünüyorlar ve bunların SES gruplarına baktığımızda onların C gruplarında D gruplarında olan kadınlar değil biraz daha yine o bahsettiğimiz A grubu B grubu kadınları, dolayısıyla bu kadınların ihtiyacı olan hikayeleri yaratmak gibi özetlenebilir yani bunlar çok da böyle sosyal hareket yaratmak değil de biraz daha onlara seslenebilmek onların ilgisini çekebilmek için üretilmiş hikayeler." (K12)

\section{Katılımcıların Kadın Temalı Reklamlardaki Ürünlere İlişkin Görüşleri}

Katılımcılar, kadın temalı reklamların kadınlara yönelik ürünlere yönelik yapıldığı konusunda hemfikirdir. Buna karşın katılımcıların bir kısmı bu durumun ürünün özelliklerinden kaynaklı olduğunu söylerken bir kısmı ise bu tarz reklamların kadınlara yönelik olmayan ürünler için yapılmasının aslında yaratıcı bir adım olabileceğini söylemişlerdir. Bu duruma ilişkin kadın katılımcılardan birinin ifadesi aşağıda yer almaktadır.

“Bu bence marka için önemli, stratejisini ona göre kuruyor, hijyenik ped reklamında tabii ki yapacak, şampuan reklamında tabii ki yapacak, ama kadın ürünü olmayan bir şeyde yapabileceğini zannetmiyorum illa ki kadınla ilgili bir şeyde bunu kullanıyor." (K12)

Kadın temalı reklamların kadınlara yönelik ürünler dışında kullanılmasının yaratıcı bir çalışma olacağına ilişkin erkek katılımcılardan birinin görüşü ise aşağıda yer almaktadır.

"Feminizmden bahsediyorsak tam tersi olması gerekiyor aslında, yani kadınlara yönelik ürünleri kaldırıp bu herkese yönelik bir ürün gibi ortaya çıkması lazım, belki o nedenle kozmetik markaları yapmıyor olsa bu çok daha farklı olur, boya markası yapıyor olsa veya erkeklerin çok kullanacağı bir marka yapıyor olsa daha da büyük bir artı sağlıyor olabilir belki de. O bakımdan yani hem daha dürüst olduğuna inanabilirim hem de bu sefer erkekleri de biraz daha düşündürtebilir yani bir tıraş bıçağının feminist bir reklam yapıyor olması çok daha enteresan olabilirdi aslında, evet zor da olur onu bir şekilde anlamlandırması ama orada daha büyük bir fikir ve daha dürüst bir şey çıkabilir belki." (K15)

\section{Kadın ve Erkek Katılımcıların Kadın Temalı Reklamlara İlişkin Görüşleri}

Kadın temalı reklamcılık uygulamalarının kadın ve erkekler tarafından algılanması teması altında oluşturulan feminizm ve kadın temalı reklamların ilişkilendirilmesi başlığında ise, kadın katılımcıların kadın temalı reklamları tanımlamaları 
istenmiştir. Katılımcılar kadın temalı reklamları bir kadın dayanışması olarak görmekte ve bir reklam hareketinden çok sosyal hareket olarak değerlendirmektedirler. Erkek katılımcılar ise bu reklamların bir "kandırmaca taktiği" olduğunu vurgularken, ürün satışına yönelik bir güdüleme olduğunu düşünmektedirler. Kadın ve erkek katıımcıların bu reklamların kadının toplumdaki yerini yansıtmadığı düşüncesinde fikir birliğine sahip oldukları bulgusuna ulaşımıştır. Bu tür reklamların bir tür pazarlama taktiği olduğu ve amacının ise daha fazla ürün satmak olduğu düşünülmektedir.

Kadın ve erkeklerin geleneksel ve çağdaş reklamlardaki kadın stereotipi hakkında görüşleri sorulduğunda ise katılımcılar geleneksel reklamlarda erkek egemen bir stereotipin olduğunu ama çağdaş reklamlarda giderek toplumun dönüşümünden kaynaklanan güçlü kadın figürünün ortaya çıktığı bulgusunda ortak görüş belirtmektedirler. Kadın katılımcılardan birinin konuya ilişkin görüşleri aşağıdaki gibidir.

"Ne yazık ki kadın stereotipi gerek geleneksel reklamlarda gerek çağdaş reklamlarda hep erkekler tarafından konumlandırılan, belirlenen bir durumdadır. Geleneksele nazaran çağdaş reklamlarda ve kadın temalı reklamcılık akımıyla kadına kendini ifade etme şansı verilen erkek hegemonyasından bir tık ayrışmışmış bir göz sunabilme imkanı tanıyan reklamlar söz konusudur." (K1)

Bir erkek katılımcının ifadesi ise aşağıdaki gibidir.

"Bir değişim mevcut ve bu değişim olumlu yönde bir değişimdir. Fakat bu tamamen pazardan gelmektedir. Kadın cinsinin iş yaşamında ve tüketim kararlarında söz sahibi olmasının artması ile bu değişim gerçekleşmiştir."(K7)

\section{Katılımcıların Kadın Temalı Reklamların Sosyal Medyada Paylaşılmasına İlişkin Görüşleri}

Kadın temalı reklamların sosyal medyada paylaşılmasına ilişkin sonuçlar incelendiğinde kadın ve erkek katılımcıların konuya ilişkin farklı görüşlerde olduğu sonucuna ulaşılmıştır. Bu durum doğrudan kişisel bir tercih olarak açıklanabileceği gibi sosyal medyada işletmelerin paylaşımlarının sosyal medyanın ilk yıllarına oranla azaldığı düşünülmektedir. Sosyal medyada paylaşım yapma ve yapmamaya ilişkin katılımcıların ifadeleri aşağıda yer almaktadır.

“Sadece Instagram'da Facebook'ta reklam olarak önüne düşüyor zaman zaman ama ben paylaşıldığını görmedim, belki de bazı ürünler direk kadın içerikli olduğu için, kadınlara hitap eden ürünler olduğu için bana gelmemiş de olabilir, kadınlar kendi arasında belki paylaşıyordur." (K13)

"Evet, beğendiklerimi paylaşıyorum. Kesinlikle kadınlarımızın bu şekilde güçlü duruşlar sergilemesini istiyorum. Yani bu reklamlarda 
gösterilen hayal dünyasının yaşadığımız coğrafyada gerçekleşmesini istiyorum." (K2)

"Sosyal medyada bu tarz reklamları, genelde reklam paylaşmıyorum eskiden, eskisi gibi insanlar artık çok paylaşım yapmıyor, bir haber belki paylaşabiliyorlar o yüzden daha çok eğlenceli içerikler paylaşıldığından reklam paylaşılmıyor belki... daha çok fenomenlerle iletişime geçme, onların paylaşmasını sağlama, belki bir miktar para verme, ünlüler, blog yazarları gibi isimlerin paylaşmasını sağlama böylece o döngüyü arttırma ve normal insanların da paylaşmasını desteklemek gibi bir süreci başlatıyor tabii reklamların da bir şekilde yaratmak istediği etki bu yani sadece TV'de yayınlanması değil sosyal medyada paylaşılması onlar için daha avantajı bütün ölçümlerini ona göre yapıyorlar zaten ama ben paylaşmayı tercih etmiyorum onun yerine daha başka bir şey paylaşıp daha farklı bir etki uyandırmayı tercih edebilirim. Ama yine de biliyorum ki insanlar etkilenip paylaşabilirler hoşlarına gidiyor böyle filmleştirilmiş bir şekilde." (K12)

\section{Katılımcıların Kadın Temalı Reklamların Ürünün Değerlendirmelerine Olan Etkilerine İlişkin Görüşleri}

Katılımcıların kadın temalı reklamların ürünü değerlendirmelerine olan etkilerine yönelik görüşlerinin farklılaştığı bulgusuna ulaşıımıştır. Katılımcılardan bir kısmı söz konusu reklamların bir ürünü satın almalarını etkilemeyeceğini belirtirken bir kısmı ise bu işletmelerin ürünlerini tercih edeceklerini belirtmişlerdir.

Konuya ilişkin olumlu görüş belirten kadın katılımcılardan birine ait ifadeler aşağıda yer almaktadır.

“Benim tercihlerimi karşıladığı sürece bir ürünle ilgileniyorum; onun dışında birebir markaları araştırmıyorum. Ancak marka ile ilgili herhangi bir haber vb. duyar ya da görürsem, etkilenir ve tercihlerimi değiştirebilirim." (K3)

Konuya ilişkin olumlu görüş belirten erkek katılımcılardan birine ait ifadeler ise aşağıda yer almaktadır.

"Erkek olarak intiyacım olabilecek bir şey ise, tercih ederim. Kadınlara tavsiye de ederim." (K6)

\section{Katılımcıların Kadın Temalı Reklamcılık Yapan İşletmelerden Sosyal Konulara İlişkin Duyarlıık Beklentilerine Yönelik Görüşleri}

Katılımcıların tamamının kadın temalı reklam çalışması gerçekleştiren işletmelerin bu duyarlııklarını daha somut birtakım etkinliklerle de kanıtlamalarını bekledikleri görülmüştür. 
Konuya ilişkin katılımcıların görüşlerine ilişkin örnekler aşağıda yer almaktadır.

“...Kadınların taciz edildiği, çocuk işçi kullanılan ya da fırsat eşitliğinin olmadığı bir şirketin ürünlerini asla almam." (K4)

Bu düşünceyi destekleyen diğer bir katılımcının düşünceleri ise aşağıdaki gibidir.

"Kadın temalı reklamları yapan markaların, kadın sayısı çalışanların sayısının önemli olduğunu düşünüyorum. Reklamlarda kullanıp kendi reel hayatında kullanmayan bir firma, bir marka ne kadar inandırıcı olabilir? Ne kadar kadınların güvenini kazanabilir?" (K6)

"Benim için ürünün işlevselliği önemlidir, reklamı değil. O ürün hangi sosyal sorumluluk projelerine bütçe ayırıyor? Kadınları kullanarak ürün satan bu firmalar, kaç kız çocuk okutuyor?" (K2)

\section{Sonuç ve Öneriler}

Kadın temalı reklamlara ilişkin derinlemesine görüşme verileri incelendiğinde kadın ve erkek tüketicilerin söz konusu reklamlara ilişkin farklı algılara sahip olduğu bulunmuştur. Görüşülen kadın katılımcıların tamamı bu reklamların ticari kaygısının olduğunu düşünmekle birlikte reklamları yine de olumluya yakın bir tutumla karşılamaktadırlar. Buna karşın, erkek tüketicilerin bir kısmı bu reklamlara olumlu bakarken, bir kısmı söz konusu reklamların kendilerini ilgilendirmediği için kendilerine bir şey ifade etmediğini belirtmişlerdir. Erkek katıımcıların bir kısmı ise bu reklamları tamamen olumsuz karşıladıklarını ve bu reklamlardan rahatsız olduklarını belirtmişlerdir. Bu durum, söz konusu reklamların bazı tüketiciler için amacının tersi bir şekilde cinsiyet farkını pekiştirdiği şeklinde yorumlanabilir.

Kadın temalı reklamların cinsiyet ayrımını pekiştirdiğine ilişkin bir başka bulgu ise reklama konu olan ürünlerin kadınlara yönelik ürünler olmasıyla ilgilidir. Katılımcıların belirttiği gibi, bu reklamlara konu olan ürünler kişisel bakım ürünleri gibi kadınlara yönelik ürünlerdir. Katılımcılardan biri erkeklere yönelik bir ürüne bu bakış açısını uyarlamanın zor olduğu kadar ilgi çekici ve ses getirici olacağını belirtmiştir.

Kadın ve erkek katılımcılar reklamlarda resmedilen kadın figürünün ülkemizin çok küçük bir kesimini temsil ettiğini düşünmektedir. Bu noktada katılımcılar, bu reklamların kadının toplumdaki dönüşümünü yansıtmak gibi ütopik bir işlevden uzak olduğu konusunda hemfikirdir. Katıımcıların bir kısmı bu reklamların hedef pazarındaki çalışan, eğitimli, kendine vakit ayıran kadın profiline uygun olduğunu belirtirken, bir kısmı ise reklamları ülke gerçeğinden ve değişim yaratma yetisinden uzak olmakla değerlendirmiştir. Katılımcılar reklamların olumlu bir duygu yaratmadan öteye gidemeyeceğini belirtmiş̧lerdir. 
Katılımcıların hemfikir olduğu diğer bir konu reklamlarda ticari kaygının yadsınamayacağıdır. Tüketiciler reklamların ilk hedefinin ticari olduğunu düşünmektedir. Reklamların ticari kaygı taşısa bile farkındalık yaratmaları özellikle kadın katılımcılar tarafından olumlu değerlendirilmektedir. Buna ek olarak, katılımcılar reklamlarda kadın kimliğinin ve cinsiyetinin bir şekilde her zaman kullanıldığını, kadınları mutlaka kullanacaksa metalaştırmadan kullanmasını daha olumlu karşıladıklarını belirtmişlerdir.

Temalarda incelenen diğer bir konu reklamların sosyal bir misyonu popülerleştirmesidir. Katıımcılar bu noktada farklı görüşlere sahiptirler. Farkındalık sağlamak ve kitlelere ulaşmak noktasında söz konusu reklamlara olumlu bakanlar olduğu gibi kavramın popülerleştirilerek içinin boşaltıldığını düşünenler de vardır. Bu noktada katılımcılardan biri Türkiye'de kavramın henüz tam olarak içeriğinin bilinmediğini belirtilmiştir. Katılımcı, feminizmin henüz tam olarak anlaşımadığı ülkemizde konuyu reklamlarda popülerleştirerek kavramın anlaşımadan işlevinden saptırılabileceğini düşünmektedir. Öte yandan, bazı katılımcılar ise reklamların herkese ulaşabilen araçlar olması yönüyle bu konuda farkındalık yaratıcı ve eğitici bir rolü olabileceğini belirtmişlerdir. Bu yönüyle farkındalık yaratmak için kavramın popülerleşmesine olumlu bakanlar da vardır.

Kavramın popülerleşmesine olumlu bakan katılımcıların uzlaştığı diğer bir konu ise reklam çabasının somut çıktısının olması gerektiğidir. Katıımcılar çeşitli sivil toplum kuruluşları ile işbirliğine giderek, kazançlarının bir bölümünü çeşitli sosyal sorumluluk projelerine aktararak, kamu kuruluşları ile birlikte çalışarak işletmelerin samimiyetlerini göstermesini beklemektedirler. Ayrıca, kadın temaIı reklam yapan işletmelere yönelik beklentilerden bir diğeri de bu işletmelerde kadın çalışanların sayısı, çalışma koşulları ve ücretleri gibi konulara hassasiyet göstermeleri yönündedir.

Kadın temalı reklamlara tüketicilerin bir kısmı gelip geçici bir moda gözüyle bakmaktadır. Katılımcıların bir kısmı her iki kavramın da gelip geçici olduğunu, bir çeşit kimlik inşa etme, farklı olmaya çalışma çabası olarak gördüklerini belirtmişlerdir. Öte yandan katıımcıların bir kısmı kadın kimliğinin toplumda dönüşeceğini dolayısıyla bu akımı gelip geçici bir moda olarak görmediklerini belirtmişlerdir.

Katılımcıların söz konusu reklamları sosyal medya hesaplarında paylaşma durumlarına ilişkin görüşleri de farklıık göstermektedir. Katııımcıların çoğu bu reklamları sosyal medya hesaplarında paylaşmadığını belirtmiştir. Bu durum tüketicilerin sosyal medya kullanımının ilk dönemlerinde olduğu kadar bu ortamlarda içerik paylaşma eğiliminde olmamalarıyla da açıklanabilir. Bu duruma çözüm önerilerinden biri katılımcılardan gelmiştir. Reklamların yayılmasında tek tek tüketicilerden değil, artık dijital mecrada söz sahibi olan fenomenleri harekete geçirmenin daha etkili olacağı belirtilmiştir. 
Çalışmanın diğer bir bulgusu ise bu reklamların satın almaya etkisi ve farkındalığı artıımadaki rolüyle ilgilidir. Katıımcıların çoğunluğu, sadece kadın temalı bir reklam olduğu için bir işletmenin ürünlerini tercih etmeyeceğini belirtmiştir. Bu noktada, işletmelere amaca yönelik pazarlama etkinlikleriyle birlikte söz konusu reklam stratejilerini şekillendirmesi önerilmektedir.

Katıımcılar kadın temalı reklam kavramı açıklandıktan sonra bu yaklaşımı benimseyen markaların isimlerini saymışlardır. Yani, katıımcıların söz konusu reklamların farkında olduğu söylenebilir. Bu durumun tüketicinin ilgilerini çekmede ve bilinirlik yaratmada kadın temalı reklamların etkili olduğunu göstermektedir. Dolayısıyla, kadın temalı reklamların marka bilinirliği yaratmada etkili olduğunu söylemek mümkündür.

Bu çalışma, kadın temalı reklamlar hakkında tüketici görüşlerini alması ve bu görüşlerin kadın ve erkek tüketiciler arasında değişip değişmediğine odaklanması yönüyle konu hakkındaki diğer çalışmalardan farklılaşmaktadır. Gerek yerli, gerek ise yabancı literatürde bu konunun genellikle doküman inceleme, içerik analizi ve söylem analizi gibi nitel analiz yöntemleriyle çalışıldığı görülmüştür. Bu çalışma, konuya ilişkin tüketicilerin değerlendirmelerini ortaya koyması bakımından önem taşımaktadır. Çalışmanın bulgularına göre kadın temalı reklamlar yapmak tüketicilerin dikkatini çektiği kadar onları işletmenin söyledikleri ile yaptıkları arasında karşılaştırma yapmaya da itmektedir. Dolayısıyla, böyle bir yaklaşım benimseyen işletmelerin kadın haklarının yanında olduğunu somut faaliyetlerle desteklemeleri gerekmektedir. Yine bulgularda bahsedildiği gibi, bu reklamların sosyal sorumluluk projeleriyle desteklenmesi de mümkündür.

Gelecekte yapılacak çalışmalarda farklı tüketici gruplarının çalışılması önerilebilir. Bu çalışma, tüketici algılarının kadın-erkek tüketicilere göre farklılığına odaklanmıştır. Gelecek çalışmalarda bu reklamların farklı kuşaklar (Y, Z kuşakları gibi) tarafından nasıl görüldüğü ve yorumlandığı incelenebilir. Bunun yanı sıra gelecekte bu konu ilişkin nicel çalışmalar da gerçekleştirilebilir.

\section{Kaynakça}

Abitbol, A., \& Sternadori, M. (2016). You Act like a Girl: An Examination of Consumer Perceptions of 'Femvertising'. Quarterly Review of Business Disciplines, 3(2), 117-128.

Akestam, N., Rosengren, S., \& Dahlen, M. (2017). Advertising "Like A Girl": Toward a Better Understanding of "Femvertising" and its Effects. Psychology \& Marketing, 34(8), 795-806.

Alkan, N. (2016). New Trends in the Representation of Women in Contemporary Media Culture: A Critical Analysis of Three Women Empowering Advertising Campaigns. Galatasaray University Journal of Communication, 24, 119-143. 
Baudrillard, J. (1998) ,The Consumer Society, Myths and Structures, Sage: London, 1998.

Baxter, A. (2015). Faux Activism in Recent Female-Empowering Advertising. Elon Journal of Undergraduate Research in Communications, 6(1).

Beale, K., Malson, H., \& Tischner, I. (2016). Deconstructing "Real" Women: Young Women's Readings off Advertising Images of "Plus-Size" Models in The UK. Feminism \& Psychology, 26(3), 378-386.

Becker-Herby, E. (2016). The Rise of Femvertising: Authentically Reaching Female Consumers. Retrieved from The University of Minnesota Digital Conservancy.

Catterall, M., Maclaran, P., \& Stevens, L. (1997). Marketing and Feminism: A Bibliography and Suggestions for Further Research. Marketing Intelligence \& Planning, 15(7), 369-376.

Champlin, S., Sterbenk, Y., Windels, K., \& Poteet, M. (2019). How Brand-Cause Fit Shapes Real World Advertising Messages: A Qualitative Exploration of 'Femvertising'. International Journal of Advertising, 1-24.

Dans, C. (2018). Commodity Feminism Today: An Analysis of the "Always Likeagirl" Campaign (Doctoral Dissertation, West Virginia University).

Drake, V. E. (2017). The Impact of Female Empowerment in Advertising (Femvertising). Journal of Research in Marketing, 7(3), 593-599.

Firat, A. F. (1991). The Consumer in Postmodernity. ACR North American Advances.

Firat, A. F., \& Venkatesh, A. (1995). Liberatory Postmodernism and the Reenchantment of Consumption. Journal of Consumer Research, 22(3), 239-267.

Fischer, E., \& Arnold, S. J. (1994). Sex, Gender Identity, Gender Role Attitudes, and Consumer Behavior. Psychology \& Marketing, 11(2), 163-182.

Gill, R. (2008). Empowerment/Sexism: Figuring Female Sexual Agency in Contemporary Advertising. Feminism \& Psychology, 18(1), 35-60.

Goldman, R., Heath, D., \& Smith, S. L. (1991). Commodity Feminism. Critical Studies in Media Communication, 8(3), 333-351.

Goulding, C. (2003). Issues in Representing the Postmodern Consumer. Qualitative Market Research: An International Journal, 6(3), 152-159.

Grau, S. L., \& Zotos, Y. C. (2016). Gender Stereotypes in Advertising: A Review of Current Research. International Journal of Advertising, 35(5), 761-770.

https://Campaignjr.Com/Femvertising-Gercekten-Kadinlari-Guclendiriyor-Mu/(Erişim Tarihi: 12.07.2018)

https://spark.adobe.com/blog/2017/03/10/femvertising-what-is-it-and-how-to-doit-well/ (Erişim tarihi: 12.07.2018) 
Hunt, A. R. (2017). Selling Empowerment: A Critical Analysis of Femvertising (Doctoral dissertation, Boston College. College of Arts and Sciences).

inceoğlu, í., \& Onaylı-Şengül, G. (2018) . Halkla illişkiler ve Reklam Çalışmaları E-Dergisi, 1(2), 20-36.

Jalakas, L. D. (2016). The Ambivalence of Femvertising: Exploring the Meeting between Feminism and Advertising through the Audience Lens (Doctoral dissertation, Master Thesis, Media and Communication Lund University).

Johnston, J., \& Taylor, J. (2008). Feminist Consumerism and Fat Activists: A Comparative Study of Grassroots Activism and the Dove Real Beauty Campaign. Signs: Journal of Women in Culture and Society, 33(4), 941-966.

Kacen, J. J. (2000). Girrrl Power and Boyyy Nature: The Past, Present, and Paradisal Future of Consumer Gender Identity. Marketing Intelligence \& Planning, 18(6/7), 345-355.

Kapoor, D., \& Munjal, A. (2019). Self-consciousness and emotions driving femvertising: A path analysis of women's attitude towards femvertising, forwarding intention and purchase intention. Journal of Marketing Communications, 25(2), 137-157.

Lazar, M. M. (2006). "Discover The Power of Femininity!" Analyzing Global "Power Femininity" in Local Advertising. Feminist Media Studies, 6(4), 505-517.

Lilburn, S., Magarey, S., \& Sheridan, S. (2000). Celebrity Feminism as Synthesis: Germaine Greer, The Female Eunuch and the Australian Print Media. Continuum: Journal of Media \& Cultural Studies, 14(3), 335-348.

Maclaran, P. (2015). Feminism's Fourth Wave: A Research Agenda for Marketing and Consumer Research. Journal of Marketing Management, 31(15-16), 17321738.

Mahdawi, Arwa, How Feminism Became a Great Way to Sell Stuff, (2014), https://www.theguardian.com/commentisfree/2014/apr/23/feminism-adverts-great-way-sell-stuff

Marcus Reker Katherine B. (2016), “'Why Can't Run 'Like a Girl' Also Mean Win The Race?": Commodity Feminism and Participatory Branding as Forms of Self-Therapy in the Neoliberal Advertising Space". Scripps Senior Theses. Paper 759. http://scholarship.claremont.edu/scripps_theses/759

Miles, S. (1999). A Pluralistic Seduction? Postmodern Consumer Research at the Crossroads. Consumption, Markets and Culture, 3(2), 145-163.

Murray, D. P. (2013). Branding "Real" Social Change in Dove's Campaign for Real Beauty. Feminist Media Studies, 13(1), 83-101.

Plank, E., 10 Worst Ways Companies Have Used Feminism to Sell Woman Products, (2014), https://mic.com/articles/91961/10-worst-ways-companies-have-used-feminism-to-sell-women-products\#.ZSXdiLmE8 
Qiao, F., \& Wang, Y. (2019). The Myths of Beauty, Age, And Marriage: Femvertising by Masstige Cosmetic Brands in The Chinese Market. Social Semiotics, $1-23$.

Retallack, H., Ringrose, J., \& Lawrence, E. (2016). "Fuck Your Body Image": Teen Girls' Twitter and Instagram Feminism in and Around School. In Learning bodies (pp. 85-103). Springer, Singapore.

Simmons, G. (2008). Marketing to Postmodern Consumers: Introducing the Internet Chameleon. European Journal of Marketing, 42(3/4), 299-310.

Sternadori, M., \& Abitbol, A. (2019). Support for Women's Rights and Feminist Self-Identification as Antecedents of Attitude toward Femvertising. Journal of Consumer Marketing.

Sylvendahl, F. (2017), Why femvertising is the future of advertising, http://www. brandba.se/blog/femvertising

Wolin, L. D. (2003). Gender Issues in Advertising-An Oversight Synthesis of Research: 1970-2002. Journal of Advertising Research, 43(1), 111-129.

Yıldıım, A., \& Şimşek, H. (2006). Sosyal Bilimlerde Nitel Arastırma Yöntemleri. Seçkin Yayıncılık.

Zmuda, N., \& Diaz, A. C. (2014). Female Empowerment in Ads: Soft Feminism or Soft Soap?. Advertising Age, 2.

Zotos, Y. C., \& Tsichla, E. (2014). Female Stereotypes in Print Advertising: A Retrospective Analysis. Procedia-Social and Behavioral Sciences, 148, 446-454. 